\title{
Loss Heterogeneity, Behavior of Asset Restructuring and the Financial Value of the Companies
}

\author{
Yong $\mathrm{Du}^{1}$, Jingxian $\mathrm{Wu}^{1}$, Bo $\mathrm{Yan}^{2} \&$ Jun $\mathrm{Du}^{2}$ \\ ${ }^{1}$ School of Economics and Management, Southwest University, Chongqing, China \\ ${ }^{2}$ School of Economics and Management, Ocean University of Guangdong, Zhanjiang, Guangdong, China \\ Correspondence: Yong Du, School of Economics and Management, Southwest University, No.2, Tiansheng \\ Road, Beibei District, 400715, Chongqing, China. Tel: 86-136-3782-9276. E-mail: dy772012@126.com
}

Received: October 23, 2013

Accepted: November 21, 2013

Online Published: January 23, 2014

doi:10.5539/ijef.v6n2p98

URL: http://dx.doi.org/10.5539/ijef.v6n2p98

\begin{abstract}
The article compared in depth and analyzed the different types of loss listed company's financial value-driven effects produced in different types of asset restructuring from a new perspective of loss heterogeneity. The study found, the financial value-driven effects produced in the asset restructuring were influenced not only by the approach, the frequency and the range of the reorganization but also the loss heterogeneity between the objects of the reorganization (ie., the loss listed companies). Namely, the different types of asset restructuring behavior will produce different effects of the financial value drivers on the same type of restructuring objects, and the same behavior of asset restructuring will produce different effects of the financial value drivers on different types of the restructuring objects.
\end{abstract}

Keywords: loss of heterogeneity, asset restructuring, financial value, drive

\section{Introduction}

In a state of loss listed company, especially those who have already been ST listed company, if not in a short period of time to achieve profitability, will face the risk of delisting. Therefore, many loss listed company management difficult to turn for the better in their own circumstances, The implementation of the reorganization of assets, or directly change the security card. For their part, the reorganization of assets is the effective means to help the torsional performance, make the dead come back to life. Jensen (1988) study, Financial distress is helpful to improve the enterprise's performance and capital structure, high corporate debt in order to avoid reducing the value of the enterprise is more willing to implement restructuring in the financial crisis. Gertner and Scharfstcin (1991) think that effective debt restructuring can increase the investment of enterprises, reason for financial distress its effectiveness depends is too little investment or over investment and capital structure. Carter (1990) pointed out that the restructuring announcement after the performance of the company increased but not because of the accounting impact of book assets but due to the economic situation after the reorganization changes bring long-term benefits. However, despite the implementation of asset reorganization or Huanshuai owners many losses into profit the listed company, shell protection to shield, but may also have negative effects of "invite wolves into the house", which have been adversity losses listed company one disaster after another, finally can only hasten their delisting or bankruptcy. Such as Magenheim and Mueller (1988) compared with the result of test of showed that after the reorganization of the company's performance has declined, Agrawal Jaffe and Mandelker (1992) found company market adjustment performance after reorganization does not rise to fall. However, despite the implementation of asset reorganization or Huanshuai owners many losses into profit the listed company, shell protection to shield, but may also have negative effects of "invite wolves into the house", which have been adversity losses listed company one disaster after another, finally can only hasten their delisting or bankruptcy. Such as Magenheim and Mueller (1988) compared with the result of test of showed that after the reorganization of the company's performance has declined, Agrawal Jaffe and Mandelker (1992) found company market adjustment performance after reorganization does not rise to fall. In addition, the reorganization of assets may be substantial performance had no effect on the loss of the listed company. Such as Bergstrom and Sundgren (2002) examines the restructuring performance of 28 companies in financial distress, the results show that after the reorganization performance and no significant change, not worth mentioning effect of financial distress on the performance of the company. Thus, effects of the assets restructuring of loss behavior of listed 
company performance or value is not stable, so, what are the causes of asset restructuring behavior influence on the loss performance of listed company or the value of unstable? Unstable phenomenon although also affect scholars perceive the reorganization of assets to the company value, but most of them are from the asset restructuring and reorganization of assets or the way of motivation to search for explanations, but there is no good explanation why the same kind of asset reorganization mode on the performance of listed company or the value of the loss will be different. As the origin, because they pay no attention to the implementation of the reorganization of assets losses listed company itself also has many differences, such as the loss of frequency, loss, loss rate and the possibility of loss reversal (here called the heterogeneity of loss). In fact, it is possible that the heterogeneity of loss between the listed company exists, which leads to even the same assets reorganization may have different effects on different types of loss performance of listed company or value, and is different for different types of assets restructuring mode loss of listed company performance or value.

Based on this, this paper puts forward from a new perspective of loss heterogeneity, financial value of assets recombination of different types of different types of loss listed company driving effect is compared and analyzed. The findings of this research, asset restructuring of loss of listed company financial value driven effect not only by the asset reorganization, restructuring and reorganization of the amplitude frequency characteristics of reflection factors of assets recombination effect, but also by the reorganization of the object (i.e., loss of listed company) loss of heterogeneity between (loss, loss, loss frequency and loss reversal the influence degree etc.). Namely: the asset restructuring behavior of different types have different financial value driving effect for the same type of the reorganization of the object, with an asset reorganization on the reorganization of objects of different types have different financial value driving effect. The significance of this research is: in theory, to further improve and enrich the connotation and characteristics of the theory of asset restructuring, development and extension of the reorganization of assets, corporate value evaluation research content; to strengthen the monitoring of the listed company asset reorganization proposal, put forward in practice, namely: to improve the supervision of the implementation of the reorganization of assets of the listed company, not only to features from the recombination frequency, restructuring and reorganization, asset reorganization of amplitude on itself, but also on the behavior subject, the implementation of the reorganization of assets reorganization, restructuring the difference of object behavior and the reorganization of the object of.

\section{Literature Review}

Research on asset restructuring impact on company performance or value has been a hot issue in academic circles and business circles. Especially in the Twelfth Five Year Plan in China today, in order to improve the rate of asset securitization, asset restructuring is an effective way to liquidize remnant assets are more popular with many listed company. In this regard, the scholars mainly reorganization of assets from the listed company's performance or value of. It includes the following three points: one is to enhance the value of recombinant. Gertner and Scharfstcin (1991) think that effective debt restructuring can increase the investment, but the reason for financial distress effectiveness depends is too little investment or over investment and capital structure. Chen Shou, Zhang Sha (2004) using the event study method to investigate 28 home ST company restructuring in 2000, the first year that the ST company after the reorganization performance increased significantly, and then two years show a downward trend; force and Liu Ying (2004) study found that mergers and acquisitions can bring the cumulative earnings target enterprises, the average cumulative excess return rate of $24.5 \%$. Li Zhe (2006) by regression method was used to investigate 1998 to 2001 reorganization of ST company, consider the possibility of recombination frequency, recombinant large-scale companies ST the larger; Lv Changiiang and Zhao Yuheng (2007) 78 ST companies uses event study examined 1999 to 2001 reorganization, restructuring that has obvious effect on ST company, recombinant with immediate effect, but the effect is limited, not after the annual overall performance improvement; Ren Ru Juan (2009) were 12 ST companies in Shanghai 2006 reorganization by case law, think short-term financial effect is the reorganization of assets behavior of ST company and improve corporate performance, but this effect do not have continuity. Zhang Tongyu and Ding Yezhen (2010), the characteristics of different recombination in different ways, after the reorganization of the performance are also different. Good short-term performance, asset sale and transfer, debt restructuring and reorganization of the mixture, poor sustainability. Long term asset restructuring performance was better than the rest of restructuring. The two is on the lower value of the reorganization. Harold Mulherin (2000) in the UK with 233 M \& A cases, found the profitability of the restructured company presented the slow decline; Bruner (2002) collects and analyzes the research on the 15 financial indicators of corporate mergers and acquisitions abroad for 1977 to 2001 years, 2 study shows the takeover performance is significantly negative, the 4 study is significantly positive, while the rest of the results was not statistically significant. Li Shanmin (2002) studies of to 2000 Shanghai two city of 1999349 M \& A events showed that, M \& A can to the shareholders of the acquiring company to bring 
significant wealth increased, while no significant influence on the Target Corp shareholders wealth. A new (2003) of 1993 to $1216 \mathrm{M} \&$ A events of 2002 China listed company is creating value are analyzed, pointed out that mergers and acquisitions created value for the Target Corp, but had a negative impact on the shareholders of the acquiring company. The three is on the independent value of the reorganization. Chen Xinyuan and Zhang Tianyu (1999) all company in 1997 in Shanghai Stock Exchange listing restructuring activities as the effects of sample inspection reorganization of the company value, the conclusion is: in the restructuring announcement, the stock price does appear fluctuation, the market reaction to the reorganization of assets. But the variance model is proved the existence of reactions, did not prove that the company value changes and equity transfer assets and asset replacement company stocks rise before announcement and then gradually declined, while the market for mergers and acquisitions, restructuring has no obvious reaction. Bergstrom and Sundgren (2002) examines the restructuring performance of 28 companies in financial distress results show that after the reorganization performance and no significant changes affecting financial distress on the performance of the company not worth mentioning. Lu Yumei (2003) the study suggests that, relative to the non asset restructuring of the listed company, the reorganization of the listed company's performance did not find significant improvement.

To sum up, the conclusion of scholars study on effect of asset reorganization of the company performance or value is not entirely consistent, the inconsistent reason mainly lies in the research perspective, research methods, performance evaluation benchmark and sample selection differences and so on. In addition, there are still defects following aspects of previous scholars on the restructuring performance or the impact problem:

It is from the point of research object, the majority of scholars will focus on various restructuring motivation has mixed listed company samples, both for expansion of motivation of merger and reorganization of these samples, also for security shell shield assets reorganization, and out of the speculative motive theme reorganization, they ignore the difference with different recombinant the motivation of listed company in the asset reorganization, restructuring performance and other aspects, there are few scholars pay attention to this difference, but it is only the ST listed company and other listed company to distinguish, recombinant specifically on the ST listed company performance analysis. This paper thinks, this division is not detailed enough, because the ST listed company is only those who have a loss for two consecutive years, although the ST listed company has strong recombination motivation losses, but the loss of only a listed company for less, avoid losses bring ST hat, can also occur recombination, and the continuous more than two losses, has not yet been delisting listed company for the last of the "life-saving straw" may also occur recombination. Similarly, Xue Shuang (2002) in the domestic first distinguish first loss and persistent loss firms conducted research on earnings management behavior, the results show that, the loss companies choose the earnings management behavior at different time. In the loss of 1 years ago, in order to delay the loss of time and the consequences brought about by this, listed company will do high profit by improving the operational effect of line project or various forms of program trading arrangements; in loss year, due to loss of company can hardly be avoided, by lowering operating accruals or line project in take a shower, and reserve space for the next year, in spite of all loss companies are significantly lower profit management behavior, but the company first loss than continuous loss of the company in the loss year earnings management level. This shows that, in the loss of the listed company, it is necessary to account for heterogeneity, loss of listed company between the therefore, we should distinguish different types of listed company, this analysis focuses on the loss of only one listed company (hereinafter referred to as the first loss of sample), continuous loss of two or more than two times of the listed company (hereinafter referred to as. Deficient sample), respectively to investigate the effect of assets reorganization on their performance or value.

The second is from the research point of view, before most studies focus on the way of assets restructuring and reorganization of assets incentive effect on firm performance or value, and most of the conclusions that the reorganization, different motives and effects on the performance of listed company or the value of the direction and the degree is different. However, due to the lack of attention to the implementation of the reorganization of assets losses listed company itself there are also different in many aspects, such as the loss of frequency, loss, loss rate and the possibility of loss reversal (this is called the heterogeneity of loss), causing them to no good explanation why the same kind of asset reorganization on the loss performance of listed company or the value of the impact will be different. In fact, it may be because of this loss of heterogeneity between the listed company, even the same asset reorganization way may have different effects on different types of loss performance of listed company or value, especially different assets reorganization way for different loss types of loss of listed company performance or value. This article is based on this, put forward from a new perspective of loss heterogeneity, on the financial value of assets recombination of different types of different types of loss listed company driving effect the detailed comparison and analysis.

The third is from the method of research, the previous studies most only the recombination events set as the 
dummy variable, this can reflect whether the loss of listed company in the recombination loss situation, did not reflect the reorganization, restructuring, reorganization, restructuring frequency direction more feature information in detail. In fact, in the event of a recombination losses listed company, due to the loss of listed company reorganization direction, mode, frequency and amplitude of restructuring has differences may exist, these differences may lead to reorganization have different influence on the loss characteristics of information listed company stock price or value differs very far, therefore, only the is obviously not reliable recombinant set as dummy variables obtained or not has effect on the loss of the listed company's stock price significantly positive effect of recombinant conclusion. Therefore, the author thinks, should reflect the loss of listed company assets reorganization activity variables are respectively arranged from the restructuring, reorganization, restructuring the direction of frequency and amplitude, restructuring behavior, distinguish different information on the characteristics of listed company value loss of a more detailed study.

\section{The Theoretical Analysis and the Research Hypothesis}

Loss heterogeneity mainly refers to the differences of various loss companies at a loss frequency and loss reversal possibility of. Researchers have found relatively late to the relationship between loss heterogeneity and the value of the company, and there are different views. Considering the heterogeneity of the deficit, foreign scholar Jenkins (2003) for the first time in accordance with the possibility of the bankruptcy of loss companies will be divided into four kinds of ruin probability in different types of samples, and conducted regression analysis, results showed that with the increase of the share of ruin probability, persistent surplus expected earnings declined. That is to say, for those who expected the surviving loss of listed company, the significant positive correlation between the rights and interests of persistent earnings and corporate value; but for those who expected bankruptcy losses listed company, its liquidation value and its value is more relevant to. After that, Peter Joos and George A. Plesko (2005) use of loss reversal model will loss the listed company to permanent loss and transient loss, the transient loss companies, due to a greater chance of loss reversal, possibility of executing the liquidation option is low, so the company value; and the possibility of turning a small permanent loss companies, means that the company had financial difficulties, is likely to perform liquidation options, therefore, its value by its liquidation value. These studies while taking into account the heterogeneity of losses, but they are not from the expected angle to explore the intrinsic value of loss companies in different types of driving factors. But the domestic has no scholars consider to distinguish research specifically on loss companies heterogeneity and various loss companies value from the expected angle. Xue Shuang (2002), Meng Yan and Yuan Chun (2004), Yuan Chun ( 2005), Xue Shuang (2008) studies of and other scholars although the overall sample and the object of study gradually from losses and profits are mixed to special groups of samples for the loss or profit company (it should be said that great progress in research thoughts and methods), however, they did not take into account the differences that exist within the loss companies. In fact, as the number of loss making listed company gradually increased, the extent and nature of the loss companies loss will be different, put all the loss companies as the study sample with a nature study, mistaken for all loss companies, between accounting earnings and stock prices are weak correlation or negative correlation, which obviously is not accurate. In this paper, considering the heterogeneity between the quasi loss companies, from the expected point analysis on the asset restructuring behavior on different types of losses in the reorganization, restructuring the listed company for second years after the first year and after the reorganization of the value driving effect (Note 1).

\subsection{The Asset Restructuring Behavior in Restructuring that Year to Heterogeneous Loss of Listed Company Value Driving}

The current regulations listed company, listed company, financial status or other abnormal conditions will be special treatment to become the ST company; general ST even lose two years with an asterisk, is the implementation of the delisting risk warning, to investors that the stock may have terminated on the city; if third years to achieve the book profits will be for their own win back three years. During this period, at least without having to face the risk of delisting; if the company losses for three consecutive years the stock is listed on the suspension of listing suspension; after the first half of the year the company has still not returned, the exchange will directly decide to terminate the listing. For the shell shield loss motivation, listed company has certain losses will, and the reorganization of assets is an important way to many losses and losses reduced listed company. However, loss of different loss listed company may have great difference in intensity, losses will return value and return options. Zhang Xin (2008) studies show that, if the loss of listed company is expected to turning hopelessness in the year, loss making listed company will choose to increase at a loss when the loss (i.e. the implementation of negative earnings management), thought that the next annual profitability ready; if the loss of listed company is expected in the year expected losses, loss of listed company will choose take positive earnings management behavior in the loss year increase in loss in earnings, in order to avoid the company at a loss when 
appear more serious loss or reduce the losses and breakeven point distance. For the first time a loss (here referred to as head loss) of listed company, since this is the first time a loss, management may blame the incidental factors or uncontrollable factors, they generally confidence in the future of the company to profitability is full, plus the first loss from the delisting standards and at least near two year buffer period, management layer may have luck or overly optimistic and relax vigilance, therefore, they use to reorganization of assets losses will not very strong, specific performance led by recombinant proportion deficient recombination frequency and small listed company low, restructuring and will be more inclined to asset replacement (Note 2). In contrast, those who have experienced loss even Kui listed company because of the losses of the previous year history, second years of losses are likely to pay more attention to the management, and the subsequent loss is likely to be a loss into profit after the implementation of product failure, this will reduce the asset management recombinant deficient confidence to a certain extent, but will increase the management of Future Ltd persistent losses or even bankruptcy of fear. In addition, even lose the listed company itself is facing greater suspended the listing or delisting risk, out of consideration for the shell shield, management will be more intense by the reorganization of assets profit motive, and because even lose two years to transition period only a year of delisting, management may be due to the psychological tension and removal of pressure to be anxious for success, therefore, even lose the listed company asset reorganization will more intense, specific performance even the recombination frequency loss listed company high and larger recombinant proportion, at the same time will be more inclined to take asset sale and transfer and debt restructuring the way (Note 3). Therefore, can make the following assumptions:

Hypothesis 1: in the restructuring that year, even lose listed company reorganization of assets will lose more strongly than the first listed company, namely: even a listed company recombination frequency and recombination ratio were significantly higher than that of the first loss of listed company.

Hypothesis 2: in the restructuring that year, even the loss of listed company assets reorganization way more inclined to the sale of assets recombination and transfer and debt, and the first loss listed company reorganization of assets way more inclined to the replacement of assets.

Hypothesis 3: in the restructuring that year, assets restructuring on even Kui listed company generated financial value driven effect was significantly higher than that of the first loss of listed company.

\subsection{The Asset Restructuring Behavior in the First Year after Restructuring to Heterogeneous Loss Listed Company Value Driving}

Considering the particularity of Chinese listed company restructuring market motivation and interest mechanism, a new (2003) proposed a "new hypothesis of value transfer and redistribution" system factors, the hypothesis that, "some restructuring itself should not occur, or after will not create value, but the system factors existing leads to transfer to other stakeholders at the expense of increased value of the restructured company, this is in fact the interests and values between the shareholders of the restructured company and other stakeholders a redistribution or transfer." According to this view, it is not difficult to speculate, recombination occurs in the short term, the Target Corp (reorganization) of the controlling shareholders and small shareholders will benefit, by recombination losses due to restructuring the listed company will be operating synergy, financial synergy effect and reduced or twisted into profit; but in the long run, recombinant behavior may also bring the negative influence to the value of Target Corp. Because the benefit compensation of the reorganizing party mainly from the primary market refinancing or two stock market speculation, if after the reorganization, restructuring found it impossible to upgrade the performance to re financing standard, or two level of market prices do not fully up, then it might to compensate themselves through the empty target listed company, which will make the loss year in restructuring the listed company future financial quality has declined, the recombination value driving effect will be reduced. Zou Huiwen (2005) the study also thinks, Chinese economy transition and the listed company of the historical background determines the existence of a large number of through the reorganization of assets is the value effect of the source of value creation, namely, management efficiency, restructuring the operating synergy, financial synergy effect, agency cost effect, underestimate the value of signal effect and other aspects of the role, the listed company's assets reorganization value effect in the short term is positive; however, according to his theoretical hypothesis, Chinese entrepreneur Shang Bu mature, like the concept of speculation, the pursuit of fashionable, enter unfamiliar areas, believe that their "error of judgment", which makes the reorganization of the company's assets with a blind so, the final result is often impaired by the reorganization of assets value of both sides.

Replacement of assets refers to the controlling shareholders of listed company to the quality of the assets or cash exchange listed company's bad assets, or to the main business of asset replacement non main business assets, 
including the overall asset replacement and partial replacement of assets and other forms of. Xiao Hong (2009) studies showed that not only the replacement of assets, the company has relatively higher profitability, growth period and the debt paying ability, but also improve the profitability of the company through related party asset replacement motivation also get some relief.

In addition, the shortcomings of corporate governance mechanism of Chinese listed company to the insider control phenomenon, independent directors and shareholders in the reorganization of assets decision can only play very little role, which makes some of the damage to the assets of the restructuring plan the future value of the company can be achieved, leading to long-term value effects of assets reorganization, the poor. Therefore, China's listed company in the reorganization of assets, the value effect in the short term is positive, but in the long term this a positive value driven weaken or even negative effect. Moreover, compared with the first loss listed company, listed company also may even lose after the reorganization of assets reorganization hollowed out and grab the interest, leading to its financial and asset quality will deteriorate faster, therefore, even a listed company produced in the reorganization of assets after the value driving effect will be more obvious changes than the first loss of listed company. Therefore, can make the following assumptions:

Hypothesis 4: in the first year after restructuring, the first loss of listed company and even the loss of listed company reorganization of assets value of the driving effect is obviously decreased.

Hypothesis 5: in the first year after restructuring, assets restructuring on even Kui listed company generated financial value driven effect change range is greater than the first loss of listed company.

\subsection{Asset Reorganization after the Restructuring of Second Years on the Heterogeneous Loss Listed Company Value Driving}

According to China's existing laws and regulations, the listed company if a loss for two consecutive years after ST, the ST is marked with an asterisk before the need to special sign, if in the ST after third years of profitability, will be for their own win back the protection period of three years, the risk that the company can effectively resist the delisting. If the company fails to realize the protection period in torsion, and three consecutive years of losses, the SFC will suspend the listing qualification. If the suspension of listing after the first year, not losses, will be delisted from the exchange to handle the. On the contrary, if the company and through the CPA examination and recognition after a profit, you can apply for resumption of listing, but with an asterisk before the name of the security. According to this stipulation, the implementation of asset restructuring behavior to turn losses if the listed company, in the first year after restructuring to achieve profitability, whether it is the first loss of listed company or continued losses listed company will receive three years of protection, which will give all kinds of losses of listed company to adjust management, reforming the business enough time, and, with the passage of time, the asset restructuring behavior brings to the loss of listed company value driving effect will gradually weaken. If in the first year after restructuring, loss of the listed company fails to recombine through asset smooth losses, for those first loss listed company, means a loss for two consecutive years, will enter the ST company ranks, at this time, the management of the company in order to avoid delisting risk warning sign company with an asterisk, will take effective measures as soon as possible to profitability however, these measures will the negative value of assets recombination offset the original on the loss of listed company drive effect to a certain extent; for those who lost money for listed company, if after the reorganization of assets a year still not turn, will fall into the plight of the losses for three consecutive years, is the ST after the first years of losses, if after the reorganization of assets of second year no losses, the company will be with "special warning signs", therefore, the management of the company will be more nervous, for the housing purposes, they will be more actively take measures to turn, at this time, the negative value effect of assets reorganization bring losses will be offset by the listed company. Therefore, can make the following assumptions:

Hypothesis 6: second years after the reorganization, the first loss of listed company and even the loss of listed company reorganization of assets value of the driving effect is obviously decreased.

Hypothesis 7: second years after the reorganization, the reorganization of assets to even Kui listed company generated financial value driven significantly effect the change extent and the first loss of listed company is not.

\section{Research and Design}

\subsection{The Selection of Samples}

To verify the above hypothesis, selected from 2003 at a loss to 2008 and at a loss when the implementation of the reorganization of assets of the listed company based samples, and according to Chen Xinyuan, Zhang Tianyu (2003) study, effects of the assets restructuring of the value of the company need time to digest the information, the market will take some time, here appropriate stretched observation window, trying to compare various 
Sample Firms at a loss ratio, the reorganization in restructuring that year, the first year after restructuring, reorganization after second years compared to the difference, may strongly in recombinant meaning restructuring the previous year of restructuring the way choice and the various ways to loss of listed company value driving effect etc.. Considering the particularity of financial statements and regulatory properties, this paper out of the financial insurance industry listed company; to ensure data integrity and accuracy, this paper also eliminate the reversal of loss data are not available and data abnormal samples, missing data collected from Chinese listed company information online by manually sorting can supplement. After the above processing, sample finally determined as shown in Table 1.

Table 1. The research sample selection process

\begin{tabular}{|c|c|c|c|c|c|c|c|}
\hline Observation of the year & 2003 & 2004 & 2005 & 2006 & 2007 & 2008 & Total \\
\hline All losses listed company annual observations & 197 & 223 & 303 & 223 & 147 & 327 & 1420 \\
\hline \multicolumn{8}{|l|}{ Eliminate: } \\
\hline Finance and insurance losses listed company & 3 & 4 & 3 & 1 & 2 & 3 & 16 \\
\hline Missing data loss listed company & 29 & 39 & 15 & 40 & 42 & 48 & 213 \\
\hline Abnormal data loss listed company & 22 & 25 & 15 & 25 & 29 & 30 & 146 \\
\hline The final choice of loss companies annual sample size & 143 & 155 & 270 & 157 & 74 & 246 & 1045 \\
\hline The sample size in the reorganization of the loss companies & 63 & 63 & 112 & 65 & 27 & 85 & 415 \\
\hline
\end{tabular}

Note: due to the sample in each year in the first year after restructuring, reorganization, reorganization after second years with respect to changes in the value of financial restructuring last year, so the actual calculation using data covering the period from 2002 to 2010 a total of nine financial year).

\subsection{To Measure the Asset Restructuring Behavior}

In order to reflect the asset restructuring behavior loss listed company occur, this paper set up all kinds of losses of listed company in four indicators recombinant proportion, recombination occurs when the frequency of recombination and recombination, recombinant amplitude to measure. Among them, recombinant proportion is in the number of losses in the reorganization of the Sample Firms accounted for the proportion of the total loss of the Sample Firms to represent; recombination frequency in loss companies in times of asset reorganization occurs when the recombinant expressed; recombinant is based on the specific transaction classes to implement the reorganization of assets, including asset sale and transfer, asset replacement, debt restructuring and reorganization of mixed type in four ways; recombination rate is the amount of the transaction related to the reorganization of assets reorganization of the proportion of total assets at the end of the said, specifically, different type of reorganization under amplitude measurement: asset sale and transfer to the sale price and reorganization of year end total assets ratio; asset replacement to set out replacement of assets price and restructuring that year end total assets ratio; debt restructuring, debt restructuring and reorganization of the amount in current year total assets ratio; mixed before the three case ratio and said.

\subsection{To Measure the Asset Reorganization Object Heterogeneity}

Heterogeneity in order to reflect the reorganization of assets loss object-listed company itself, the loss of the sample according to the loss of continuity is divided into the first deficiency group and even deficiency group, 0 said even deficiency group, with 1 representing the first loss group.

\subsection{To Measure the Loss of Listed Company Financial Value Driven Effect}

The present research in the event study method and case method, only selected a few sample data analysis, the inspection efficiency is low, and the research of event study method of stock price to reflect the degree of recombination events, through the car before and after the reorganization of the news announced stock calculated to evaluate the performance of the asset restructuring. The method is based on two assumptions: one is the capital market is effective, the value of the company is fully reflected in the stock price changes; two is in the event window in the absence of other factors affecting the stock price. Zhao Xi and Zhou Jun (2008) think, because of China's capital market is still very young, strong market speculation, the intrinsic value of the stock price can not reflect the stock. To make up for the shortcomings of previous studies, this paper collects the sample data are selected, the annual loss of Sample Firms in the reorganization of assets, restructuring of the 
previous year nine indexes of first year, after the reorganization and restructuring after second years of annual report values (including reflect company profitability index: operating profit ratio, net asset interest rates, earnings per share; reflect the company's operating capacity indicators: total asset turnover ratio; reflect the company's solvency indicators: the ownership equity ratio, current ratio, quick ratio; reflect the company's development capacity indicators: the growth rate of total assets, operating income growth rate) as the object of study, using the factor analysis method to study the comprehensive factor score second years of losses in the reorganization, restructuring the listed company after the first year, after the reorganization, the changes of factor scores to measure the assets restructuring of loss for the listed company's financial value driving effect is different, and compared and analyzed the driving effect of recombinant, recombination frequency and the reorganization of assets recombination rate the various types of losses of listed company financial value.

\section{Research Methods}

In order to fully reflect the implementation of the reorganization of assets overall Sample Firms operating conditions, we selected nine indicators of the Sample Firms in 2003 to 2008 year-end report value as the research object, the comprehensive factor score calculated by the method of principal component analysis to examine the various types of losses in the reorganization, restructuring the listed company after the first year, second years after the reorganization changes in the value of financial restructuring last year, to verify the asset restructuring behavior of various losses of listed company financial value driven effect size and persistence.

\subsection{The Appropriate Test Factor Analysis}

In the factor analysis to correlation of the original variables to test the first, this paper uses KMO test and the Bartlett test, the 4 observation period data of the test results in Table 2.

Table 2. The test results of KMO test and bartlett ball

\begin{tabular}{|c|c|c|c|c|c|}
\hline Period & & $\begin{array}{l}\text { Restructuring the } \\
\text { previous year }\end{array}$ & $\begin{array}{l}\text { Restructuring } \\
\text { that year }\end{array}$ & $\begin{array}{l}\text { The first year } \\
\text { after restructuring }\end{array}$ & $\begin{array}{l}\text { Second years after } \\
\text { the reorganization }\end{array}$ \\
\hline KMO Value & & 0.604 & 0.620 & 0.592 & 0.567 \\
\hline \multirow{2}{*}{$\begin{array}{l}\text { Bartlett } \\
\text { ball test }\end{array}$} & Chi square value & 2445.118 & 1933.769 & 1601.784 & 1206.507 \\
\hline & $\begin{array}{l}\text { Concomitant } \\
\text { probability }\end{array}$ & 0.000 & 0.000 & 0.000 & 0.000 \\
\hline
\end{tabular}

From Table 4 can, before the reorganization, restructuring that year, a year after the reorganization, restructuring of the first year after second years of KMO values were $0.604,0.602,0.592$ and 0.567 , were higher than the 0.5 usually standard; concomitant probability Bartlett ball test was 0 , lower than the significance level 0.10 , test results show that each year the sample used for factor analysis.

\subsection{Extraction Factor}

In this paper, using the principal component extraction method of factor analysis, a set number of factor extraction was 5, the 4 observation period of data analysis results are shown in Table 3 . 
Table 3. Factor variance contribution rate

\begin{tabular}{|c|c|c|c|c|c|c|}
\hline \multirow{2}{*}{$\begin{array}{l}\text { Period } \\
\text { Factor }\end{array}$} & \multicolumn{2}{|c|}{ Restructuring the previous year } & \multirow[b]{2}{*}{$\begin{array}{l}\text { The cumulative } \\
\text { variance } \\
\text { contribution rate } \\
(\%)\end{array}$} & \multicolumn{3}{|c|}{ Restructuring that year } \\
\hline & $\begin{array}{l}\text { The } \\
\text { variance } \\
\text { contribution }\end{array}$ & $\begin{array}{l}\text { The variance } \\
\text { contribution } \\
\text { rate }(\%)\end{array}$ & & $\begin{array}{l}\text { The } \\
\text { variance } \\
\text { contribution }\end{array}$ & $\begin{array}{l}\text { The variance } \\
\text { contribution rate } \\
(\%)\end{array}$ & $\begin{array}{l}\text { The cumulative } \\
\text { variance contribution } \\
\text { rate }(\%)\end{array}$ \\
\hline 1 & 2.802 & 31.130 & 31.130 & 2.855 & 31.726 & 31.726 \\
\hline 2 & 2.097 & 23.302 & 54.431 & 1.984 & 22.043 & 53.768 \\
\hline 3 & 0.977 & 10.856 & 65.287 & 1.220 & 13.556 & 67.325 \\
\hline 4 & 0.916 & 10.178 & 75.465 & 0.882 & 9.795 & 77.120 \\
\hline 5 & 0.818 & 9.0910 & 84.556 & 0.707 & 7.851 & 84.971 \\
\hline Period & \multicolumn{2}{|c|}{ The first year after restructuring } & & \multicolumn{3}{|c|}{ Second years after the reorganization } \\
\hline Factor & $\begin{array}{l}\text { The } \\
\text { variance } \\
\text { contribution }\end{array}$ & $\begin{array}{l}\text { The variance } \\
\text { contribution } \\
\text { rate }(\%)\end{array}$ & $\begin{array}{l}\text { The cumulative } \\
\text { variance } \\
\text { contribution rate } \\
(\%)\end{array}$ & $\begin{array}{l}\text { The } \\
\text { variance } \\
\text { contribution }\end{array}$ & $\begin{array}{l}\text { The variance } \\
\text { contribution } \\
\text { rate }(\%)\end{array}$ & $\begin{array}{l}\text { The cumulative } \\
\text { variance contribution } \\
\text { rate }(\%)\end{array}$ \\
\hline 1 & 2.769 & 30.763 & 30.763 & 2.371 & 26.345 & 26.345 \\
\hline 2 & 1.764 & 19.600 & 50.364 & 1.800 & 19.998 & 46.343 \\
\hline 3 & 1.172 & 13.023 & 63.387 & 1.397 & 15.522 & 61.865 \\
\hline 4 & 1.012 & 11.248 & 74.635 & 1.011 & 11.232 & 73.097 \\
\hline 5 & 0.885 & 9.836 & 84.471 & 0.847 & 9.415 & 82.512 \\
\hline
\end{tabular}

In Table 3, the variance contribution rate of each factor is used to measure the original data interpretation ability, the ability to explain the cumulative contribution of variance to measure the 5 factors on the original data of total To observe the accumulated variance contribution rate can be seen, in the previous year, restructuring restructuring that year, the first year after restructuring, reorganization after second years, 5 factors on the original data general explanation ability is respectively $84.556 \%, 84.971 \%, 84.471 \%$ and $82.512 \%$, are close to the $85 \%$ level, suggesting that the 5 common factors reflect most information of original data, factor analysis is an ideal effect.

\subsection{According to the Factor Score Function for Each Sample Were Calculated in the Score of Each Factor Recombinant Year}

Factor score function for each sample:

$$
F A C_{i j}=\sum \alpha_{i m j} X_{i m}, i=1,2, \ldots, n ; j=1,2, \ldots, 5 ; m=1,2, \ldots, 9 ;
$$

Among them,the $F A C_{i j}$ scores for the I sample in the $j$ factor, the $\alpha$ imj is I samples of the M primitive indexes in the $\mathrm{j}$ factor, the value obtained directly from the component score coefficient matrix, Xim is the first I samples of the $\mathrm{M}$ primitive indexes, $\mathrm{n}$ said all kinds of sample size.

\subsection{According to the Variance Contribution Rate of Each Factor Were Calculated in Recombinant Factor When the Score}

Comprehensive factor score function for each sample:

$$
F A C_{i}=\sum \beta_{i j} F A C_{i j}, i=1,2, \ldots, n ; j=1,2, \ldots, 5 \text {; }
$$

Among them, $F A C_{i}$ is the I sample scores in comprehensive factor recombinant was; rate of $\beta_{i j}$ contribution to the variance in I samples in the $\mathrm{j}$ factor; FACi scores for the I sample in the $\mathrm{j}$ factor.

According to the above steps of using SPSS13.0 can be calculated for each sample score, in the comprehensive factor recombinant the and so on, comprehensive factor score can be calculated for each sample in a year, in the first year after restructuring, before the reorganization after the reorganization of second years, and then to the comprehensive factor score mean difference that the implementation of the reorganization of assets of financial value drivers effect, then compare the first loss and even loss of sample group reorganization value driven effect and persistence. 


\section{Empirical Analysis}

\subsection{Descriptive Statistics Analysis}

6.1.1 The Annual Sample and Full Sample in Proportion and the First Loss, Recombination Loss Comparison

Table 4. The first loss group and even deficiency group in restructuring the proportion of recombinant comparison table

\begin{tabular}{|c|c|c|c|c|c|c|c|}
\hline Observation of the year & 2003 & 2004 & 2005 & 2006 & 2007 & 2008 & Total \\
\hline $\begin{array}{l}\text { The final choice of loss companies annual } \\
\text { sample size }\end{array}$ & 143 & 155 & 270 & 157 & 74 & 246 & 1045 \\
\hline $\begin{array}{l}\text { The total number of samples in the } \\
\text { recombination loss }\end{array}$ & 63 & 63 & 112 & 65 & 27 & 85 & 415 \\
\hline The first loss of sample number & 61 & 61 & 88 & 30 & 18 & 83 & 341 \\
\hline $\begin{array}{l}\text { The number of the first loss in a sample of } \\
\text { recombinant }\end{array}$ & 29 & 18 & 35 & 9 & 8 & 20 & 119 \\
\hline $\begin{array}{l}\text { Recombinant proportion the first loss in a } \\
\text { sample }\end{array}$ & $47.54 \%$ & $29.51 \%$ & $39.77 \%$ & $30.00 \%$ & $44.44 \%$ & $24.10 \%$ & $34.90 \%$ \\
\hline Even the loss of the number of samples & 82 & 94 & 182 & 127 & 56 & 163 & 704 \\
\hline $\begin{array}{l}\text { Even the loss of recombinant number } \\
\text { samples }\end{array}$ & 34 & 45 & 77 & 56 & 19 & 65 & 296 \\
\hline $\begin{array}{l}\text { Even the loss of sample recombinant } \\
\text { proportion }\end{array}$ & $41.46 \%$ & $47.87 \%$ & $42.31 \%$ & $44.09 \%$ & $33.93 \%$ & $39.88 \%$ & $42.05 \%$ \\
\hline
\end{tabular}

Note: here even deficit including intermittent multiple losses and continuously occurred repeatedly loss in two cases.

The data in Table 4 shows, from the above the first loss samples and even deficient sample recombination occurs in the proportion of each year, except in 2003 and 2007, the rest of the year even deficient sample recombination ratio was significantly higher than that of the first loss of samples, and 2003 to 2008 in all samples, even deficient sample recombinant proportion also obviously higher than the first loss of samples, which demonstrated that in the restructuring that year, even lose listed company reorganization of assets will lose more strongly than the first listed company. At the same time, we presume that in 2003 and 2007 the first loss of sample recombination occurs abnormal ratio higher than even the new accounting standards event loss possible samples and in 2003 the beginning of the implementation of special treatment regulations according to the provisions of the listed company and losses related to the implementation of the 2007 . To further confirm the first loss samples and even loss difference in recombination rate of the sample, the author draws the trend of change observed various loss companies sample recombinant proportion, from Figure 1 shows that, during the whole observation, even the change trend of deficient sample recombination ratio and the first loss samples recombinant proportion change trend is just the opposite, which leads to the full sample recombinant proportion showed no obvious change in different years. 


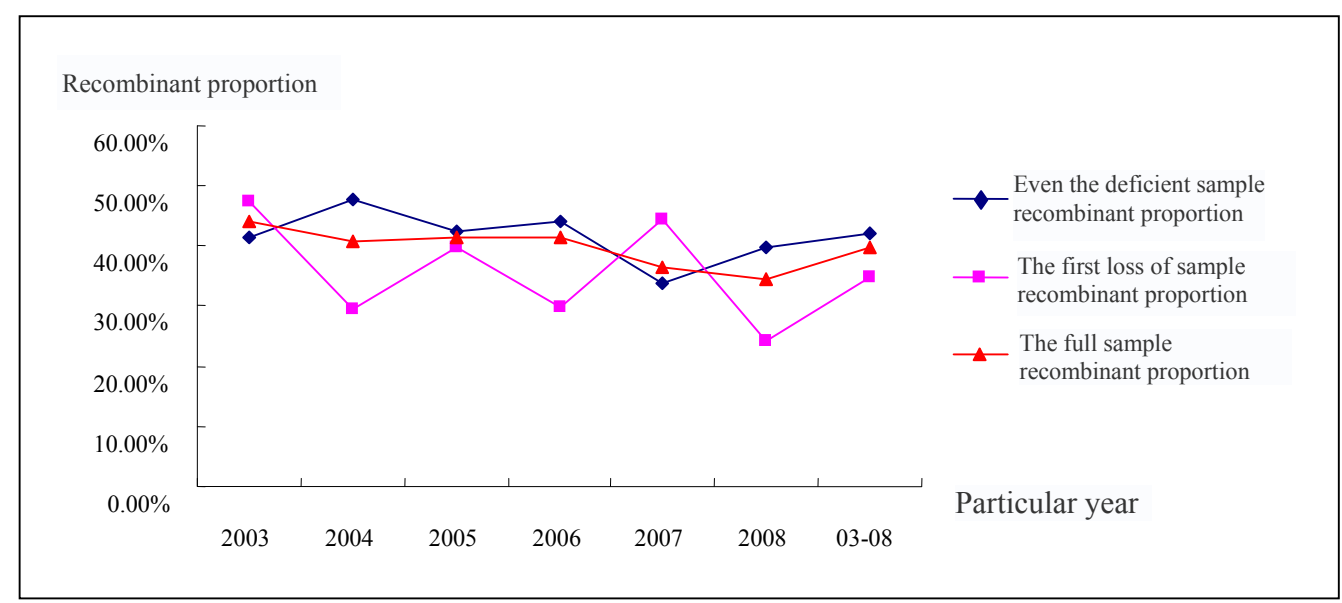

Figure 1. Loss companies to sample recombinant proportion trend chart

\subsubsection{The First Loss of Sample Group and Recombinant Frequency}

In the whole sample period, the first loss of sample group and recombinant frequency and amplitude even deficit recombinant sample comparison.

Table 5. Reorganization and restructuring the mean and median frequency amplitude of each sample group

\begin{tabular}{|c|c|c|c|c|c|c|}
\hline \multirow{2}{*}{$\begin{array}{l}\text { The classification of } \\
\text { samples } \\
\text { Recombinant variables }\end{array}$} & \multicolumn{2}{|c|}{$\begin{array}{l}\text { The first loss of } \\
\text { samples (116) }\end{array}$} & \multicolumn{2}{|c|}{$\begin{array}{l}\text { Even the loss of } \\
\text { samples }(280)\end{array}$} & \multicolumn{2}{|c|}{ Two sample comparison } \\
\hline & The mean & Median & The mean & Median & Mean comparison & The median comparison \\
\hline $\begin{array}{l}\text { Recombination } \\
\text { frequency (CZPL) }\end{array}$ & 1.5345 & 1 & 1.9250 & 1 & $3.119^{* *}$ & 2.855 \\
\hline $\begin{array}{l}\text { Recombination rate } \\
\text { (CZFD) }\end{array}$ & 0.0711 & 0.0332 & 0.1204 & 0.0620 & $3.710 * * *$ & $3.371 * *$ \\
\hline $\begin{array}{l}\text { The degree of loss } \\
\text { reversal(KSNZ) }\end{array}$ & 0.0584 & 0.0486 & 0.1864 & 0.0982 & $2.952 * *$ & $15.666^{* * *}$ \\
\hline
\end{tabular}

Note: 1 means comparison report is $\mathrm{t} \mathrm{T}$ statistics test, the median comparison report is the Mann-Whitney $\mathrm{U} \mathrm{Z}$ test statistics, ***, **, * denote significant in statistical levels $1 \%, 5 \%, 10 \%$. Table 2, sample 5 and follow-up in each table is from recombinant proportion sample (415) from 19 companies restructuring amplitude anomaly of the years, finally retained 396 firm years.

Comparison of results from Table 5 reports the sample frequency and amplitude of recombination between recombinant mean and median shows: even the loss of recombination frequencies mean recombination frequencies mean sample in the statistical level of 5\% was higher than the first loss of sample group, but no difference between the two types of samples of recombinant median frequency; even the deficient recombine ant frequency mean recombination rate the mean sample in the statistical level of $1 \%$ was higher than the first loss of samples, and even the loss of median recombinant amplitude sample in the statistical level of $5 \%$ sample groups was significantly greater than the first loss of the median frequency of recombination. These instructions even deficient recombinant frequency and amplitude of the sample group were significantly higher than the first loss of samples, combined with recombinant proportion front analysis result, further proof that even deficient recombinant will sample is higher than that of the first loss of samples, which confirmed the hypothesis above 1. In addition, the statistical results also show, even the loss of samples after the reorganization losses mean reversal degree in statistics at 5\% level was higher than the first loss of samples, and the reversal of loss, even the median loss reversal degree deficient samples after the reorganization occurred in the statistical level of $1 \%$ sample groups was significantly greater than that of the first loss these preliminary results suggest that deficiency, even sample group in the restructuring performance of the reorganization may first loss than restructuring performance of sample group of higher. 


\subsubsection{The First Loss of Sample Group and Recombinant Deficient Sample Group}

In the whole sample period, the first loss of sample group and recombinant deficient sample group.

Table 6. The first loss and even loss in assets reorganization in the reorganization analysis table

\begin{tabular}{llllll}
\hline Recombination & $\begin{array}{l}\text { The sale and transfer } \\
\text { of assets }\end{array}$ & $\begin{array}{l}\text { Replacement } \\
\text { assets }\end{array}$ & $\begin{array}{l}\text { Debt } \\
\text { restructuring }\end{array}$ & $\begin{array}{l}\text { Hybrid } \\
\text { recombinant }\end{array}$ & Total \\
\hline The first loss of samples & 79 & 18 & 8 & 11 & 116 \\
The proportion of & $68.10 \%$ & $15.52 \%$ & $6.90 \%$ & $9.48 \%$ & $100 \%$ \\
Even the loss of samples & 167 & 25 & 41 & 47 & 280 \\
The proportion of & $59.64 \%$ & $8.93 \%$ & $14.64 \%$ & $16.79 \%$ & $100 \%$ \\
Total & 246 & 43 & 49 & 58 & 396
\end{tabular}

Note: the Ruisi database classification method of asset restructuring of the way, it will be divided into asset sale and transfer, replacement of assets, debt restructuring, reorganization of the four kinds of mixed.

See from the results in Table 6, in the entire sample period, the first loss of samples of restructuring of the order from high to low for the asset sale and transfer, asset replacement, mixed restructuring, debt restructuring; even a sample group of reorganization of the order from high to low for the asset sale and transfer, mixing, debt restructuring restructuring and asset replacement. This text with the hypothesis 2 is not completely consistent, the first loss group and even deficiency group considering restructuring options are asset sale and transfer, for the loss of listed company, regardless of is the first loss or consecutive losses, the sale of assets and transfer them into the preferred way is surplus, the reason may be because existing in China capital market, the implementation of asset sale constraints and transfer is relatively less, for the loss of a listed company can save transaction cost benefits to them; secondly, for the first loss group, select the replacement of assets restructuring mode before the debt restructuring, for even deficiency group, choice of debt restructuring in the asset replacement before, that even the losses were more likely to choose the restructuring effect of recombinant fast, restructuring and the first loss groups tend to choose heavy group effect slower.

\subsection{Analysis of the Effect of Asset Reorganization on the Loss of Sample Overall Value Driving}

Table 7. The whole sample statistic significant difference

\begin{tabular}{|c|c|c|c|c|c|c|c|}
\hline \multicolumn{8}{|c|}{ Paired Samples Test } \\
\hline \multirow{2}{*}{ With $\log$} & \multirow{2}{*}{$\begin{array}{l}\text { The comprehensive scores of } \\
\text { each period sample difference }\end{array}$} & \multicolumn{3}{|c|}{ Paired Differences } & \multirow{2}{*}{$\mathrm{T}$} & \multirow{2}{*}{$\mathrm{df}$} & \multirow{2}{*}{$\begin{array}{c}\text { Sig. } \\
\text { (2-tailed) }\end{array}$} \\
\hline & & Mean & Std. Deviation & Std. Error Mean & & & \\
\hline Pair 1 & FAC0 - FAC_1 & 0.000 & 0.541 & 0.027 & 0.000 & 395.000 & 1.000 \\
\hline Pair 2 & FAC1 - FAC_1 & 0.000 & 0.585 & 0.029 & 0.000 & 395.000 & 1.000 \\
\hline Pair 3 & FAC2 - FAC_1 & 0.003 & 0.565 & 0.028 & 0.089 & 395.000 & 0.929 \\
\hline Pair 4 & FAC1 - FAC0 & 0.000 & 0.463 & 0.023 & 0.000 & 395.000 & 1.000 \\
\hline Pair 5 & FAC2 - FAC1 & 0.003 & 0.487 & 0.024 & 0.104 & 395.000 & 0.918 \\
\hline
\end{tabular}

In Table 7, FAC_1, FAC0, FAC1, FAC2 respectively represent the first year of implementation of the reorganization of assets losses in the previous year, listed company reorganization restructuring that year, after the reorganization and restructuring of the second year after the comprehensive factor score. From the comparison of the results of the paired, paired two tailed t test significance levels close to or is 1 , far higher than the significance level 5\%, that means every two annual comprehensive score no significant difference before and after the reorganization, the financial value of all samples did not change significantly, which shows in the before and after the reorganization of assets, asset reorganization from the whole and did not produce significant financial value of losses listed company drive effect. 


\subsection{The Influence of Drive Effect Heterogeneity of Loss on the Reorganization of Assets Restructuring of the Object Value}

If there is a significant difference between the behavior of asset reorganization to test whether there is significant financial value to each sample and their driving effect, here for a single sample mean test and independent samples test statistics of packet loss based on frequency, the results are as follows:

Table 8. Packet statistics and its significant difference test results (One-sample test and independent samples test)

\begin{tabular}{|c|c|c|c|c|c|c|c|c|c|}
\hline \multirow{2}{*}{$\begin{array}{l}\text { The overall } \\
\text { score }\end{array}$} & \multirow{2}{*}{ KSPL } & \multirow[t]{2}{*}{$\mathrm{N}$} & \multirow{2}{*}{ Mean } & \multicolumn{2}{|c|}{ One-Sample Test } & \multicolumn{2}{|c|}{$\begin{array}{c}\text { Levene's Test for } \\
\text { Equality of Variances }\end{array}$} & \multicolumn{2}{|c|}{$\begin{array}{c}\text { t-test for Equality } \\
\text { of Means }\end{array}$} \\
\hline & & & & $\mathrm{T}$ & Sig. & $\mathrm{F}$ & Sig. & $\mathrm{t}$ & Sig. \\
\hline \multirow{2}{*}{ FAC0_1 } & 0 & 280 & 0.002 & 0.069 & 0.945 & \multirow{2}{*}{1.454} & \multirow{2}{*}{0.229} & 0.135 & 0.893 \\
\hline & 1 & 116 & -0.006 & -0.131 & 0.896 & & & 0.146 & 0.884 \\
\hline \multirow{2}{*}{ FAC1_1 } & 0 & 280 & 0.053 & 1.412 & 0.159 & \multirow{2}{*}{2.993} & \multirow{2}{*}{0.084} & 2.818 & 0.005 \\
\hline & 1 & 116 & -0.128 & -3.068 & 0.003 & & & 3.225 & 0.001 \\
\hline \multirow{2}{*}{ FAC2_1 } & 0 & 280 & 0.086 & 2.483 & 0.014 & \multirow{2}{*}{0.363} & \multirow{2}{*}{0.547} & 4.700 & 0.000 \\
\hline & 1 & 116 & -0.199 & -4.587 & 0.000 & & & 5.134 & 0.000 \\
\hline \multirow{2}{*}{ FAC10 } & 0 & 280 & 0.051 & 1.787 & 0.075 & \multirow{2}{*}{1.366} & \multirow{2}{*}{0.243} & 3.420 & 0.001 \\
\hline & 1 & 116 & -0.122 & -3.167 & 0.002 & & & 3.611 & 0.000 \\
\hline \multirow{2}{*}{ FAC21 } & 0 & 280 & 0.033 & 1.098 & 0.273 & \multirow{2}{*}{0.494} & \multirow{2}{*}{0.482} & 1.960 & 0.051 \\
\hline & 1 & 116 & -0.072 & -1.813 & 0.072 & & & 2.107 & 0.036 \\
\hline
\end{tabular}

*. The mean difference is significant at the 0.05 level. in the loss frequency (KSPL) variable, 1 said that the first loss group (116), 0 consecutive loss group (280).

In Table 8, FAC0_1 said the implementation of the reorganization of assets losses of listed company in the comprehensive factor score of recombinant the comprehensive factor score and reorganization of the previous year difference, can reflect the asset restructuring behavior in the reorganization in the value of the loss of listed company drive effect size; FAC1_1 said poor comprehensive factor score and the scores of the first years of restructuring factor one year before the implementation of the reorganization of assets losses listed company after the restructuring, which can reflect the asset reorganization in the first year after restructuring of listed company have loss of value driving effect size; FAC2_1 said implementation of the reorganization of assets losses after the reorganization of listed company in second comprehensive factor score and the scores of years of recombinant factor of the previous year the difference, can reflect the asset reorganization after the restructuring of the listed company second years loss value of the driving effect size; FAC10 said implementation of the reorganization of assets losses of listed company in the first year after restructuring and reorganization of the comprehensive factor score of comprehensive factor score was poor, can reflect the asset restructuring behavior in the reorganization in the listed company production losses value driven effect last year 1 after the restructuring; FAC21 The implementation of the reorganization of assets loss factor score of comprehensive listed company in the first year after second years of restructuring and reorganization after the comprehensive factor score difference, can reflect the asset restructuring behavior in the first year after restructuring the listed company produces loss value driving effect in recombinant after second continuous years.

According to the first loss group and even deficiency group do one sample test (test value is 0 ), from table 8 , FAC0_1, FAC1_1, FAC2_1 levels in each group was significant to know: the asset reorganization year in the reorganization of assets relative to restructuring the previous year, both for the loss or even on the first loss group, there wasn't significant difference in financial value driven effect; asset reorganization after the reorganization of assets relative to a year before the first year of restructuring, the even deficiency group is still no significant value driving effect, but for the first loss in statistical level of 5\% produced a reverse value obviously driven effect, which reduces the first loss group financial value; asset reorganization in second years after the reorganization restructuring relative to a year ago, the first loss in statistical level of $5 \%$ produced a reverse value obviously driven effect, for even deficiency group in statistics at $5 \%$ level have positive value obviously driven effect, which reduces the first loss group financial value, enhance the financial value of a group. These show that 
the asset restructuring behavior, though not to the whole sample of obvious value driven effect, but the grouping of samples according to the loss frequency has obvious value driven effect, however, this value can only be driven effect will be after the reorganization of the year reflected, which has lagged behind, and this effect will reduce the first loss group samples of the financial value, will improve even Kui samples financial value. The reason may be the first loss group more is no statement reorganization substantial help for loss of listed company, and even deficiency group under the delisting pressure and achievement projects, more preference to be able to generate value promotion effect on the loss of substantial restructuring for listed company.

From table 8 FAC10 levels in each group were showed: after the reorganization of assets relative to the first year of restructuring, asset restructuring behavior on even deficiency group generated financial value driven effect increased significantly in statistics at $10 \%$ level, while the asset restructuring behavior on the first loss of group financial value decreased significantly in the driving effect statistical level of 5\%, it could not confirm the above assumption 4, the reason is that even the loss of the listed company's management more prone to substantial restructuring, the value driving effect tend to lag behind, and the first loss of listed company management more tend to form on the restructuring, the value driving effect is often temporary so, resulting in the first year after restructuring, even the restructuring of value loss group driving effect enhancement, and the restructuring of value the first loss group driving effect. From Table 8 FAC21 levels in each group were showed: after the reorganization of assets second years compared with the first year after restructuring, asset restructuring behavior on even deficiency group of financial value and promote the effect did not change significantly, but the asset restructuring behavior on the first loss of group financial value reduction effect obvious decline in the level of statistics $10 \%$ the above hypothesis, which could not be confirmed 6 , this shows that even a group of the reorganization of assets value and promote the effect is persistent, and the first loss of the reorganization of assets to reduce the value of group effect is transient characteristic.

The first loss group and even deficiency group do the independent sample test, we can see from the results in table 13 of FAC0_1, Levene test significance level in more than $5 \%$, indicating that two groups of sample variance is homogeneous, the significance level $\mathrm{T}$ test corresponding also is in $5 \%$ above, in the reorganization of assets that, relative to assets a year before the reorganization, asset restructuring behavior driven significant difference effect had no effect on the first loss group and even deficiency group generated financial value, shows that the above assumption 3 does not hold, the reason may be the effects of assets reorganization lag caused by, in the restructuring that year, asset restructuring behavior of various losses of listed company financial value driven effect is not clear, cause the difference between them was not significant.

We can see from the results in Table 8 of FAC1_1, FAC2_1, Levene test significance level in more than 5\%, indicating that two groups of sample variance is homogeneous, the significance level $\mathrm{T}$ test corresponding to less than $5 \%$, in the first year after the reorganization of assets and restructuring after second years, compared with the previous year, assets reorganization, assets reorganization on the first loss and even loss of group financial value driven effect exists obvious difference, and driven from the comprehensive score of each value effect mean, asset restructuring behavior on even the deficient groups generated value driven effect was significantly higher than that of the first loss group value decreases the driving effect, which confirms the above assumption 5 , in the first year after restructuring, assets restructuring on even Kui listed company generated financial value driven effect change range is greater than the first loss of listed company.

We can see from the results in Table 8 of FAC10, Levene test significance level in more than 5\%, indicating that two groups of sample variance is homogeneous, the significance level $\mathrm{T}$ test corresponding to less than $5 \%$, the reorganization of assets after the first year of relative to assets restructuring that year, asset restructuring behavior on even deficiency group of financial value effect the first loss was significantly higher than that of group financial value reduction effect, which confirmed the above hypothesis 5; known from statistical results in Table 7 of FAC21, Levene test significance level in more than 5\%, indicating that two groups of sample variance is homogeneous, the corresponding $\mathrm{T}$ test level was significantly higher than that of $5 \%$, the assets reorganization after the first year compared to second years after the reorganization of assets, asset restructuring behavior on the first loss samples and even deficient samples generated financial value driving effect had no difference, which confirmed the above assumptions 7 , second years after the reorganization, the reorganization of assets to even Kui listed company generated financial value driven significant difference effect the change extent and the first loss of listed company is not. These results show that: considering the difference in the loss frequency of recombination sample should be in the reorganization of assets assessment of performance, and once again confirmed the first loss group are more inclined to form of asset restructuring, and even deficiency group are more inclined to substantial asset restructuring, validate the robustness of the conclusions. 


\section{Research Conclusion and Enlightenment}

In this paper, from a new perspective of loss heterogeneity, on the financial value of assets recombination of different types of different types of loss loss listed company driving effect in-depth comparison and analysis, the study found, assets restructuring of loss of listed company financial value driven effect not only by the asset reorganization, restructuring and reorganization of the amplitude frequency factors reflecting the reorganization of assets the act itself characteristics of the impact, but also by the reorganization of the object (i.e., loss of listed company) losses between the effects of heterogeneity. Namely: the asset restructuring behavior of different types have different financial value driving effect for the same type of the reorganization of the object, with an asset reorganization on the reorganization of objects of different types have different financial value driving effect. Specifically, in the restructuring that year, even lose listed company reorganization of assets will lose more strongly than the first listed company, namely: even a listed company recombination frequency and recombination ratio were significantly higher than that of the first loss of listed company, but also the first loss group and even deficiency group considering restructuring options are asset sale and transfer. From the asset restructuring behavior of heterogeneous samples generated financial value driven effect, asset restructuring behavior despite the absence of the entire sample of obvious value driven effect, but the grouping of samples according to the loss frequency has obvious value driven effect, however, this value can only be driven effect only in the reorganization of the years reflect, which has lagged behind, and this effect will reduce the first loss of samples of financial value, will improve even Kui sample financial value, in the first year after restructuring, assets restructuring on even Kui listed company generated financial value driven effect change range is greater than the first loss of listed company, but also the first loss group may more inclined to form of asset restructuring, and even deficiency group may be more inclined to substantial asset restructuring.

Research implications of this paper is: in the reorganization of assets assessment of performance should not only consider the reorganization, restructuring and reorganization frequency amplitude reflects the reorganization behavior characteristic factor of itself, should also take into account the heterogeneity in recombination sample loss frequency, loss of historical condition. This provides a new perspective for the Commission to strengthen the supervision of the listed company, which is to improve the supervision of the implementation of the reorganization of assets of the listed company, not only features from the restructuring, reorganization and restructuring the amplitude frequency and pay attention to the assets reorganization behavior itself, but also on the heterogeneity of asset reorganization object. This requires the listed company in the disclosure of the relevant asset restructuring information, will target companies before restructuring losses in history, current losses, the possibility of a reversal of loss of more detailed information to all the investors and explained, in order to ensure that investors can the loss of listed company assets reorganization value effects are properly identified and reasonable assessment.

\section{Acknowledgements}

The authors are grateful for financial support from the fund of the Ministry of education of Humanities and social sciences research Youth Project (11YJC630243, 12YJC630010, and 13YJC630027), Central University basic research funds in Southwest University (SWU130911, SWU1309202).

\section{References}

Bergström, C., Eisenberg, T., \& Sundgren, S. (2002). Secured debt and the likelihood of reorganization. $\begin{array}{lllll}\text { International Review of Law and } & \text { Economics, }\end{array}$ http://dx.doi.org/10.1016/S0144-8188(01)00075-8

Bruner, R. F., \& Does, M. (2002). Pay: A survey of evidence for the decision-maker. Charlottesville, VA: University of Virginia.

Carter, R. B., \& Manaster, S. (1990). Initial public offerings and underwriter prestige. Journal of Finance, 45(4), $1045-1068$.

Chen, S., \& Zhang, S. (2004). Special treatment companies restructuring empirical study on performance evaluation. Management Review, (12).

Chen, H., \& Zhang, T. (1999). Asset restructuring market reaction—1997 Shanghai asset restructuring empirical analysis . Economic Research, (9), 47-55.

Gertner, R., \& Scharfstein, D. (1991). A theory of workouts and the effects of reorganization law. Journal of Finance, 46(4), 1189-1222.

Harold, M. J., \& Boone, A. L. (2000). Comparing acquisitions and divestitures. Journal of Corporate. 
Jenkins, D. S. (2003). The transitory nature of negative earnings and the implications for earnings prediction and stock valuation. Review of Quantitative Finance \& Accounting, 21(4), 379-404. http://dx.doi.org/10.1023/B:REQU.0000004784.30694.0c

Jensen, M. C., \& Warner, J. B. (1988). The distribution of power among corporate managers, shareholder, and directors. Journal of Financial Economics, 20(1/2), 3-24. http://dx.doi.org/10.1016/0304-405X(88)90038-4

Jeffrey, F., \& Mandelker, G. N. (1992). The post-merger performance of acquiring firms: A re-examination of an anomaly. Journal of Finance, 47(4), 1605-1621. http://dx.doi.org/10.1111/j.1540-6261.1992.tb04674.x

Li, Z. (2006). Support, recombination and ST's “ST” road. Nankai Business Review, (6).

Lv, C., \& Zhao, Y. (2007). Study on financial problem of analysis of ST company reorganization of survival.

Li, S., \& Chen, Y. (2002). The wealth effect of mergers and acquisitions of listing. Corporation.Economic Research, (11), 27-35.

Lu, Y. (2003). Asset restructuring of listed companies performance analysis. Liaoning Technical University (Social Science Edition), (3), 29-31.

Magenheim, E., \& Mueller, D. C. (1988). Are acquiring firm shareholders better off after an acquisition? Oxford University Press.

Meng, Y., \& Yuan, C. (2004). Loss of value related to the public company accounting earnings empirical study. Accounting Research, (9), 42-46.

Peter, J., \& George, A. P. (2005). Valuing loss firms. The Accounting Review, 80, 847-870. http://dx.doi.org/10.2308/accr.2005.80.3.847

Ren, R. (2009). Analysis of asset restructuring performance of ST companies based on financial indicators. Management Information in China, (6).

Yuan, C. (2005). Earnings quality and value relevance: Empirical evidence from Shenzhen. Economic Theory and Business Management, (8), 36-39.

Xue, S. (2008). Economic cycle, the industry boom and loss firms Pricing. Management World, (7), 145-150.

Xue, S. (2002). Loss company's stock price is how to determine? Chinese Accounting and Finance, (4), $100-115$.

Zhang, X. (2003). Whether mergers and acquisitions create value? Economic Research, (6), 20-29.

Zhang, X., \& Hu, D. (2008). Loss of listed companies will profit in the fourth quarter smooth? China Accounting Review, (3).

Wen, Z., \& Tang, B. (2004). Market portfolio of risky assets alternatives theoretical discussion. China Management Science, (5), 17-22.

Zhao, X., \& Zhou, J. (2008). A major asset restructuring of listed companies performance evaluation. Southwest Jiaotong University (Social Sciences Edition), (5), 13-16.

Zhang, T., \& Ding, Y. (2010). An empirical study of asset restructuring performance of ST companies in China.

\section{Notes}

Note 1. Here the value driving effect refers to the assets reorganization activities (including restructuring, reorganization and restructuring of the frequency range) to the Target Corp (reorganization, here refers to all kinds of losses affect the value of the sample).

Note 2. Replacement of assets refers to the controlling shareholders of listed company to the quality of the assets or cash exchange listed company's bad assets, or to the main business of asset replacement non main business assets, including the overall asset replacement and partial replacement of assets and other forms of. Xiao Hong (2009) studies showed that not only the replacement of assets, the company has relatively high growth period, the profitability and solvency, and improve company profitability by related party asset replacement motivation also get some relief.

Note 3. Because the asset sale and transfer of the whole sale and transfer of assets of the listing Corporation, so the quality can rapidly increase, income also can establish lever to see a movie; the divestiture of non-performing assets or sell assets and business not related to improve asset management capabilities, to highlight the main industry, but also have large sums of cash inflows, increases the debt paying ability. Therefore, the sale of assets and transfer by the theory and the practice is generally considered the more quickly the assets reorganization. 
Debt restructuring is the listing Corporation in order to reduce the burden of debt restructuring the listing Corporation to improve financial structure, it can greatly reduce the company's debt ratio, significantly improve the company's equity ratio, improve the company's assets, therefore, a debt restructuring is a restructuring way more quickly.

\section{Copyrights}

Copyright for this article is retained by the author(s), with first publication rights granted to the journal.

This is an open-access article distributed under the terms and conditions of the Creative Commons Attribution license (http://creativecommons.org/licenses/by/3.0/). 